Article

\title{
Use of GIS Tools for Environmental Conflict Resolution at Map Ta Phut Industrial Zone in Thailand
}

\section{Phattraporn Soytong ${ }^{1}$ and Ranjith Perera ${ }^{2, *}$}

1 School of Environment, Resources and Development, Asian Institute of Technology, Bangkok, Thailand and Faculty of Geo-Informatics, Burapha University, Chonburi Province 20131, Thailand; E-Mail: phattraporn@buu.ac.th

2 Department of Civil and Architectural Engineering, Sultan Qaboos University, P.O. Box 33, P.C. 123 Al Khoudh, Oman

* Author to whom correspondence should be addressed; E-Mail: ranjith@squ.edu.om; Tel.: +968-2414-2505; Fax: +968-2414-1331.

Received: 24 December 2013; in revised form: 18 March 2014 / Accepted: 11 April 2014 / Published: 25 April 2014

\begin{abstract}
Special industrial zones are favored over scattered industries from an environmental management perspective, but poor management can lead to conflicts. This paper presents an analysis of the environmental conflict that arose between the state, society, and industry stakeholders in an industrial zone of the Eastern Seaboard Development Program of Thailand. This paper seeks to determine the effectiveness of policy measures implemented by the state to resolve the conflict. The purpose of this study is to draw lessons for industrializing nations that adopt the industrial zone model to foster environmentally sustainable industrial development. The study revealed that blatant violation of land-use planning regulations and expansion of the industrial zone into community areas was a root cause of the conflict. Through legal action, civil society has been successful in forcing the state and industries to halt unplanned expansion of industrial areas and practice better environmental governance. However, inadequate commitment by the state and industry stakeholders seems to perpetuate the conflict, threatening the sustainability of economic gains. A Geographic Information Systems (GIS)-based analysis confirmed that the policy interventions of the government to resolve the conflict have not produced significant results. This paper highlights the need for GIS-based environmental quality monitoring for guiding industrialization-based urban development towards sustainability.
\end{abstract}


Keywords: industrialization; industrial zone model; environmental conflict resolution; spatial analysis; air pollution; water pollution; public health

\section{Introduction}

Since the 1960s, some countries in Asia have pursued industrialization-based urban development [1]. Among them, Japan and South Korea have experienced endogenous development of their urban and industrial sectors. In contrast, foreign direct investments (FDIs) have played a major role in the industrialization of countries like Thailand, Malaysia, and Vietnam [2]. Industrialization-based urbanization is associated with massive transformation of the physical, social, economic, political, spatial, and environmental facets of urbanizing areas. Environmental transformation has attracted special attention since the emergence of sustainable development paradigms in the 1980s [3]. Environmental problems associated with urbanization and industrialization that contravene sustainable development include haphazard sprawl of built-environment, land-use conflicts, natural resource depletion, environmental pollution, ecological destruction and public health impacts. Planned industrial zones offer better prospects for minimizing negative environmental consequences than small industrial sites scattered over large areas, because agglomeration of functionally related industries and centralized treatment facilities are advantages of industrial zones [4]. However, if environmental management is done poorly, industrial zones pose greater threats due to the accumulation of pollution loads beyond the carrying capacity of the ecosystem.

The Map Ta Phut industrial zone in the Eastern Seaboard Development Program (ESBDP) of Thailand gained notoriety as a locality where mismanagement of industrial expansion and industrial pollution resulted in large negative environmental impacts [5]. The Map Ta Phut industrial zone (see Figure 1) is highly successful in terms of stimulating economic growth and urban development of the Eastern Sea Board (ESB) [6], and was hailed as an exemplary industrial development model [7]. Nevertheless, negative environmental impacts accumulated over two decades have diminished its economic gains and social acceptance. Presently, Map Ta Phut is a socio-environmental "hotspot" in Asia. Some critics branded it "Thailand's Minamata", referring to the infamous industrial toxic pollution case in Japan [8]. There are worries about alarming health problems related to air and water pollution in the Map Ta Phut industrial zone. Worries over these problems have pitted civil society stakeholders against the state on one side and the industrialists on the other. This is predominantly an environmental conflict, because conflicting parties were having different opinions about the status of the environmental quality. It has raged for a long period of time and came to a stalemate by 2007. The Thai Government implemented policy measures to resolve the conflict using a win-win approach. These are mostly environmental management measures. The outcomes of the measures are communicated to the stakeholders as conventional environmental quality indicators and indices.

This paper examines the usefulness of GIS-based monitoring to complement conventional environment monitoring and public informing. It is presented in two parts. The first part presents a chronological review of the conflict based on published literature. The literature originated from state institutions, industrial establishments, the scientific community, non-governmental organizations, and 
public media. These were analyzed to review the story of the conflict in an unbiased manner. Using GIS a tool, the second part of the paper examines whether the Government's policy interventions have resolved the conflict and turned Map Ta Phut industrial zone towards the path of sustainable development. Before reviewing the conflict in Map Ta Phut in detail, a brief theoretical construct of conflicts and conflict resolution is presented below.

Figure 1. Location of the provinces of the Eastern Sea Board (ESB) area in relation to the Bangkok Metropolitan Region (BMR).

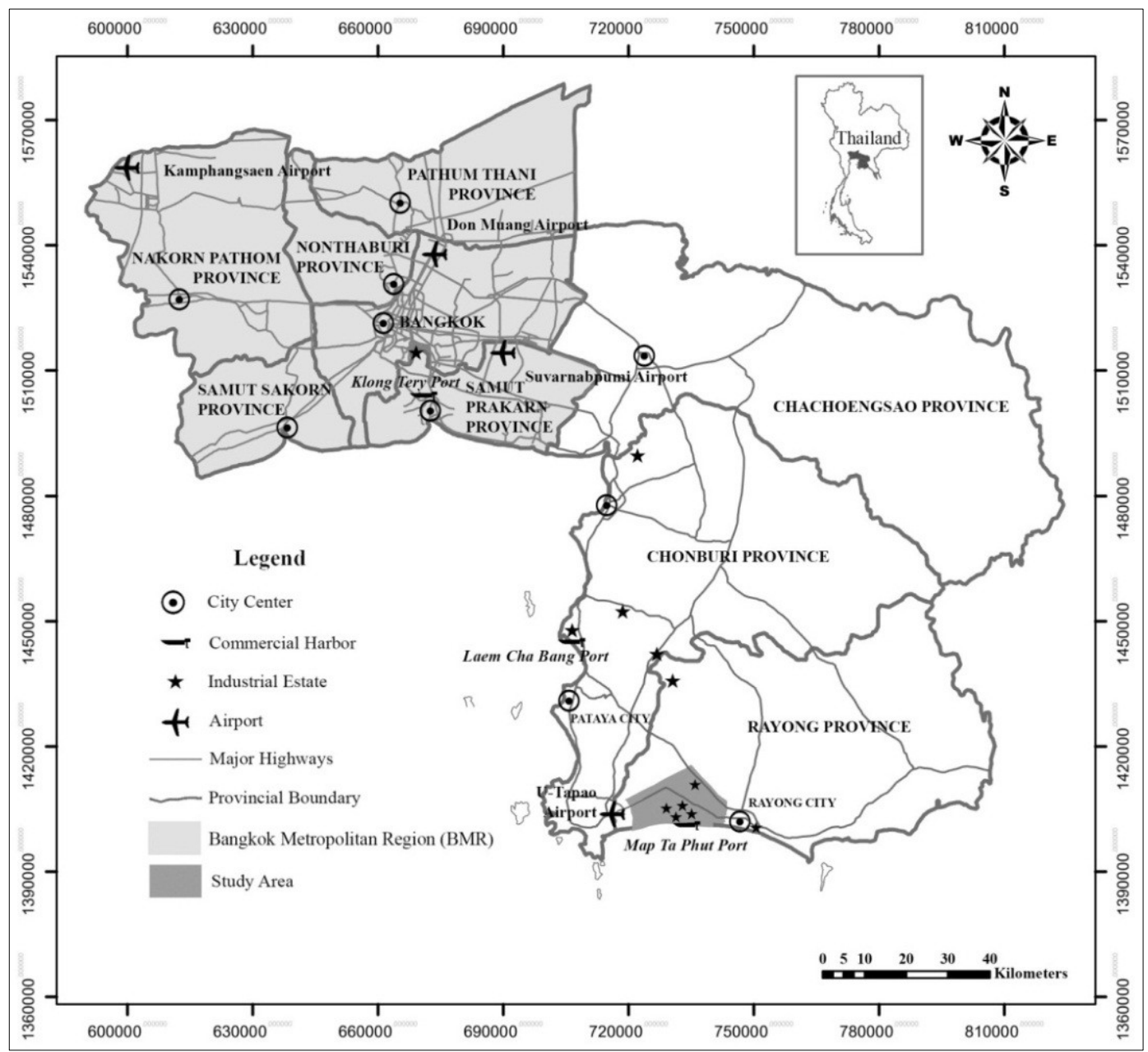

\section{Conflict Theory and Conflict Resolution}

A conflict is defined as "a struggle over values and claims to status, power, or resources in which the aim of the conflicting parties is to neutralize, injure, or eliminate the rivals" [9]. From another viewpoint, conflict is a violent dispute or an incompatibility of positions [10]. According to Mack and Snyder [11], the term "conflict" refers to a range of phenomena that can be identified or characterized by four conditions: (1) the existence of two or more parties, (2) a situation of resource scarcity, (3) the presence of behavior that hurts and injures another, and (4) mutually opposed goals. These conditions are explained as the necessary empirical conditions to confirm the existence of a conflict.

One of the key issues in the analysis of any conflict concerns the identity of the parties. It is an analytical construct referring to the parties that initiate a conflict, pursue it and determine its outcome. 
Possible classification of parties in a conflict could include individuals, groups, communities, states, regions, and sectors [10]. Conflicting parties often disagree on the issues of conflict or on what the conflict is all about. For example, one party may see the issues in conflict as pertaining to the right of self-determination, while the other may see them as pertaining to its security and survival [10]. Generally there are two kinds of issues at stake in situations of conflict. These are issues expressing disagreement over means and issues expressing disagreement over ends. The former occurs in situations where the parties agree on what they want, but disagree on how to obtain it. The latter characterize conflict situations where the parties differ on what they want.

In situations of conflict, parties' behaviors can be described as either: (1) assertive - the extent to which the parties attempt to satisfy their interests, or (2) cooperative - the extent to which the parties attempt to satisfy other parties' interests [12]. According to Thomas et al. [12], conflict resolution is easy if all parties equally benefit (i.e., win-win). However, it is extremely difficult when gains for one party occur at the loss to another (i.e., win-loss). Parties may be motivated for win-win solutions when there is: (1) a desire to cooperate on common interests, and (2) a desire to get a fair share of the resources.

Conflict analysis is a method of developing a multi-dimensional understanding of the causes and dynamics of conflict [13]. Conflict analysis is taking snapshots of situations. Our analysis followed this concept using available literature. It is recommended that a timeline of events be constructed from different perspectives [13]. We used the State's policy interventions since 1961 as one perspective and reports from the civil society (i.e., the public, civil society organizations, academia) as another perspective. The conflict mode analysis instrument of Thomas et al. [12], known as TKI (The Thomas-Kilmann Conflict Mode Instrument), was used to understand the status of conflict resolution in the Map Tha Phut industrial zone when it turned into a legal battle in 2007. According to TKI, there are five modes of handling a conflict. These are competing, collaborating, compromising, avoiding, and accommodating [13]. The goal of the competing mode is to win over the other conflicting party or parties. Therefore this approach is assertive and uncooperative. The collaborative mode aims for assertive and cooperative solutions, which are win-win solutions. The compromising mode aims to find middle ground through assertiveness and cooperation. The avoiding mode aims to delay and, hence, it is unassertive and uncooperative. The accommodating mode aims to yield and is therefore cooperative and unassertive. Consideration of these modes of conflict analysis suggests that the collaborative mode is the best, because it satisfies the concerns of all parties involved.

\section{Chronology of the Conflict}

The Thai Government implemented the ESBDP in 1982. One of its goals was to divert new industrial investments from the Bangkok Metropolitan Region (BMR) to alternative growth centers [14]. The first phase of the ESBDP covered the area of Chacheangsao, Chonburi, and Rayong provinces in the eastern region (see Figure1). The plan for the first phase proposed to establish natural gas-based petro-chemical industries and heavy industries in Rayong Province after the discovery of natural gas deposits in the Gulf of Thailand in 1973 [15]. Chacheangsao Province and Chonburi Province were designated to serve agro-industries and light industries, respectively. Thirty years of relentless development has turned the ESB into the largest industrial conglomeration in Southeast Asia [16]. About 6730 industrial developments were established in the ESB during this period. As a result, the 
industrial sector's share of the Gross Regional Product of the ESB increased from $26.5 \%$ in 1980 to $44.8 \%$ in 2012 [17].

Land development for the Map Ta Phut industrial estate started in the mid-1980s. A comprehensive plan for the Map Ta Phut municipal area prepared by the Department of Town \& Country Planning (DTCP) in 1988 recognized the location of this industrial estate and demarcated an area south of Sukhumvit Road (i.e., National Highway No.1) as an industrial zone. Figure 2a shows the industrial zone surrounded by a buffer zone consisting of agricultural and forest land. This was a conventional land-use planning strategy practiced at that time [18]. In reality, there were residential and agricultural communities scattered within the buffer zone. Due to rapid industrial expansion, industrial activities spread beyond the demarcated industrial zone, thereby violating land-use regulations of DTCP. The comprehensive plan for the Map Ta Phut municipal area was revised in 1991 to enlarge the industrial zone as depicted in Figure 2b. Normally, comprehensive plans are revised by DTCP every 5 years. In effect, revising the plan legitimized the land-use violations of the industrial sector. During the decade of the 1990s, more residential and agricultural land was converted to industrial activities by again violating the land-use zoning regulations of the revised comprehensive plan [5]. The industrial zone was expanded to almost three times its original size by the early 2000s. The DTCP once again legitimized industrial expansion in their comprehensive plan prepared for Map Ta Phut municipal area in 2003 (see Figure 2c). This meant that the industrial zone's expansion was not a result of a planned development. Instead, the plans prepared by DTCP were to legitimize land-use conversions that contravened its own planning regulations. Critics recognize this bizarre approach to urban development planning as the root cause of the environmental conflict that ensued in Map Ta Phut [19,20]. People protested against the DTCP's approach of modifying land-use zones to benefit influential people with vested interests. As a result, the revised comprehensive plan of 2011 reduced the extent of the industrial zone as shown in Figure 2d.

Figure 2. Successive comprehensive plans of the Map Ta Phut municipal area.

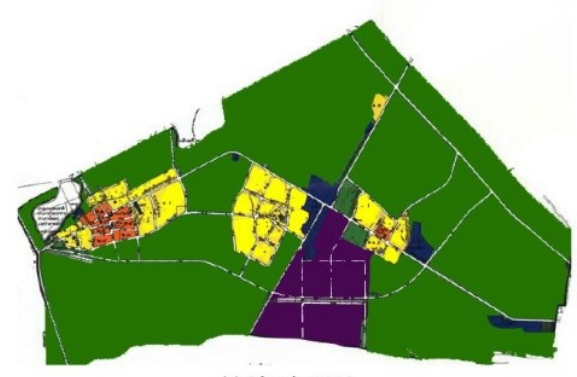

(a) Plan in 1988

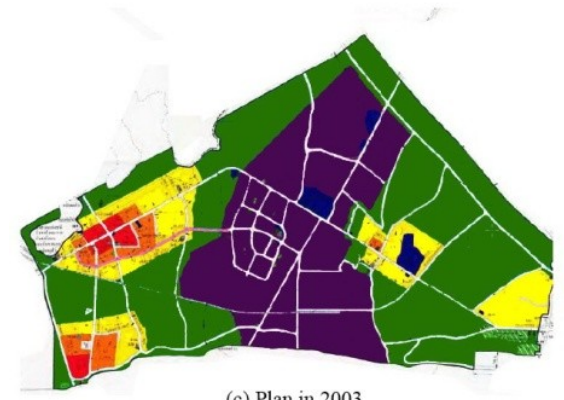

(c) Plan in 2003
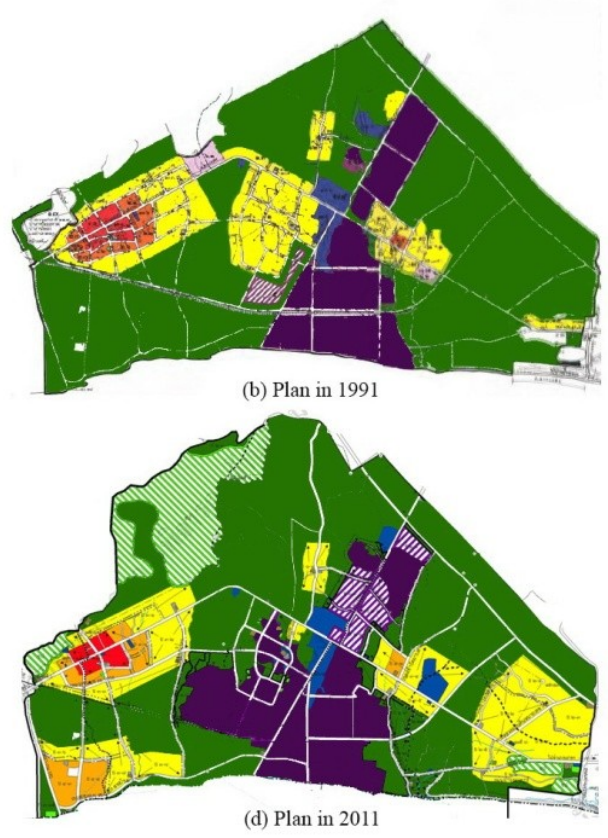

Note: purple—industrial area; green—agriculture and forest area; yellow—residential area. Source: [21]. 
Division of responsibilities for planning and plan implementation is a factor that contributes to the violation of regulations. Although the DTCP prepares the comprehensive plan, the Map Ta Phut Municipality is responsible for its implementation. As an ordinary local government body, it has very limited capacity to deal with non-compliance to regulations. It does not have the political power and authority to overrule larger state organizations that promote industrial investments, such as the Industrial Estates Authority of Thailand (IEAT) and the Department of Industries (DoI). This explains why DTCP had to validate illegal land-use conversions by subsequent comprehensive plans.

Industrial land development, both planned and unplanned, has caused many environmental and health problems [22]. People have been particularly concerned about air pollution by industries and the respiratory problems they experienced [23]. A research study has shown links between exposure of residents and industrial workers to air pollutants and the increase in diseases related to the respiratory, nervous, reproductive, and muscle systems [7]. Some researchers stress that Volatile Organic Compounds (VOCs) pose the highest health risks for people in Map Ta Phut [24]. A test carried out by the Global Community Monitor has revealed that VOCs, such as benzene, vinyl chloride, and chloroform, released by some industries in the Map Ta Phut industrial zone exceeded safety standards of developed nations by 60 to 3000 times [25].

Polluted surface water has been linked to skin and bowel diseases in Map Ta Phut residents [26]. Surface water in the Map Ta Phut industrial zone and its vicinity has been found to be contaminated with metallic compounds. Samples tested from 25 water bodies revealed the presence of cadmium in concentrations more than six times the level that is regarded as safe for human contact. The presence of zinc, manganese, lead, and iron in the water samples exceeded safe levels by factors of 10, 34, 47, and 151, respectively [27]. A communiqué issued by the Public Health Office of Rayong Province in 2005 warned people not to use ground water in Map Ta Phut municipal area for drinking, due to iron, lead, manganese, and, chloride contamination [7].

Concerns over public health issues came to the spotlight when a Thai national university and an Italian research team reported that among the 76 provinces in Thailand, "rates of cervical, bladder, breast, liver, nasal, stomach, throat, and blood cancers are highest in the Rayong province", where Map Ta Phut industrial zone and many other scattered industries are located [28]. A study by the National Cancer Institute and the Rayong Public Health Office revealed that the incidence of cancer in Rayong Province was 182.45 per 100,000 people compared to the national average of 122.6. The same study has reported that the incidence of birth deformities and chromosome abnormalities was 163.8 per 100,000 people compared to the national average of 48.2 [7]. These findings have exacerbated the anxiety of Map Ta Phut residents about the health risks that they endure.

The alarming extent of air and water pollution, occasional industrial accidents, and associated health risks have provoked Map Ta Phut residents to request that the government introduces strict measures to curb industrial pollution and safeguard their lives. During one severe incident in 1997, a toxic gas leak from a factory caused children and teachers of a nearby school to fall ill. Later the whole school was relocated to a safer place. It was arguably the incident that triggered a series of protests and actions by community groups [25]. They had been requesting that the government declared Map Ta Phut as a pollution control zone even before this incident [28]. However, any policy decisions declaring Map Ta Phut as a pollution control zone were resisted by industrialists. They threatened to relocate industries to other countries if the government introduced strict environmental management 
measures (EMMs). Fearing serious economic consequences, the government continued to ignore the predicament of the local residents. Consequently, these were very critical of the government for placing the interests of the investors above the health and safety of the public. These disagreements developed into conflicts between the communities and industries as well as the communities and the government. The government was in a dilemma, because it has a moral duty to safeguard the interests of the public, but also needs to address national economic interests to facilitate the investors.

Sensing the stalemate, 27 people representing 11 communities in the Map Ta Phut industrial zone filed a lawsuit against the National Environment Board (NEB) in Rayong Administrative Court in 2007. They accused NEB of failing to designate Map Ta Phut municipal area and its vicinity as a pollution control zone. In its March 2009 verdict, the court ruled that NEB was negligent in not declaring Map Ta Phut a pollution control zone. The court ordered NEB to declare the zone within 60 days. In April 2009 NEB declared the pollution control zone (see Figure 3). Another law suit filed by some community organizations and an environmental NGO accused NEB, the Ministry of Industry, the Ministry of Energy, the Ministry of Natural Resources and Environment, and the IEAT for failing to issue operating licenses to 76 new industrial expansion projects following the prescribed procedure [29]. In September 2009, the administrative court issued an injunction to suspend those projects until they obtain clearances following environmental and health impact assessments (i.e., Environmental Impact Assessment-EIA and Health Impact Assessement-HIA).

This was a landmark court ruling in Thailand. It shocked both the Thai Government and the international business community. The loss of investment due to this court ruling has been estimated to be 8 billion USD [30]. Hence, the government appealed the ruling at the request of industrialists. It received the court's permission in December 2009 to proceed with 11 projects under the condition that it meets environmental and health impact assessment requirements. In an attempt to ensure effective solutions of the problems upon the court's decisions, the Thai government took a win-win approach to safeguard the public, while continuing to act in the interests of investors. The Thai government, through NEB, promulgated an environmental management plan titled, "Pollution Mitigation and Elimination" [22,31]. The plan had the following 5 objectives:

(1) To reduce the emissions of air and water pollutants and to assure disposal of solid and industrial waste according to legal requirements.

(2) To improve the water and air quality to an acceptable level within one year.

(3) To provide health care, treatment, and rehabilitation to the public in a fair and thorough manner.

(4) To enhance the community's continuous participation in monitoring the environmental quality and the generation of pollution at the source.

(5) To ensure that future development will be in accordance with the area's comprehensive plan and not affect the environment and public health.

The Thai Government allocated 877 million Baht (28 million USD) for its line agencies to implement the plan. Installation of automatic VOC monitoring equipment, water quality monitoring equipment, and establishment of an environmental quality surveillance center within the Map Ta Phut Municipality were the most significant actions taken. Moreover, the Pollution Control Department (PCD) installed information displays at two locations in Map Ta Phut to show the daily environmental 
status [31,32]. These displays are the primary instruments to communicate environmental quality monitoring information to interested parties.

Figure 3. Pollution control zone demarcated by NEB (adapted from [21]).

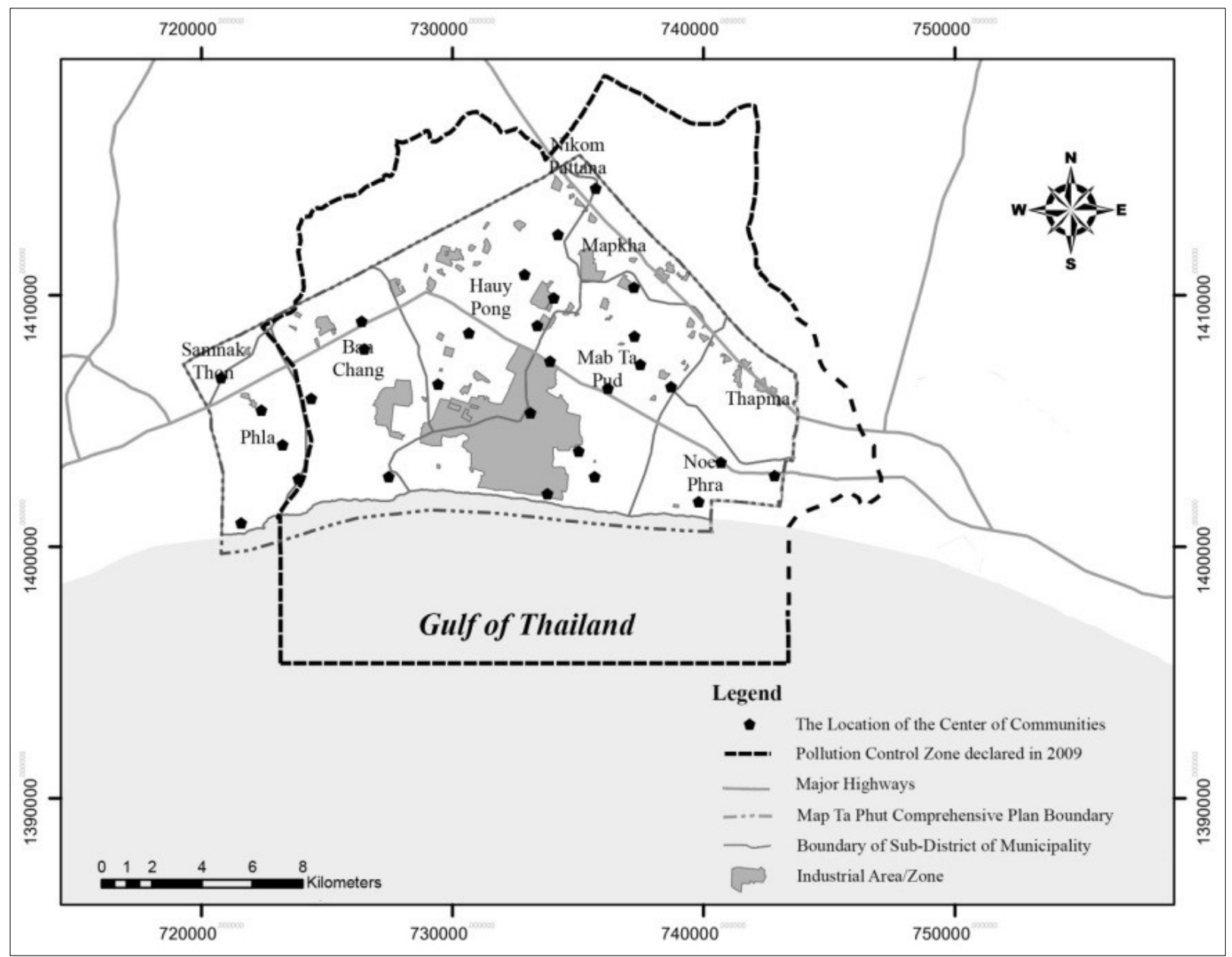

The chronology of the major events since the inception of Map Ta Phut industrial zone is summarized in Figure 4. It shows that the saga of Map Ta Phut is not over. Even after declaring Map Ta Phut a pollution control zone and implementation of the environmental management plan, there were several major incidents, including chemical leakage and accidents [33]. It is questionable whether the government's policy interventions are producing intended results. If the plan was effective, the environmental status in Map Ta Phut should indicate an improving trend towards sustainable industrial development. The empirical part of this paper attempts to verify the effectiveness of the government's intervention. 
Figure 4. Chronology of major policies and landmark incidents related to Map Ta Phut Industrial Zone.

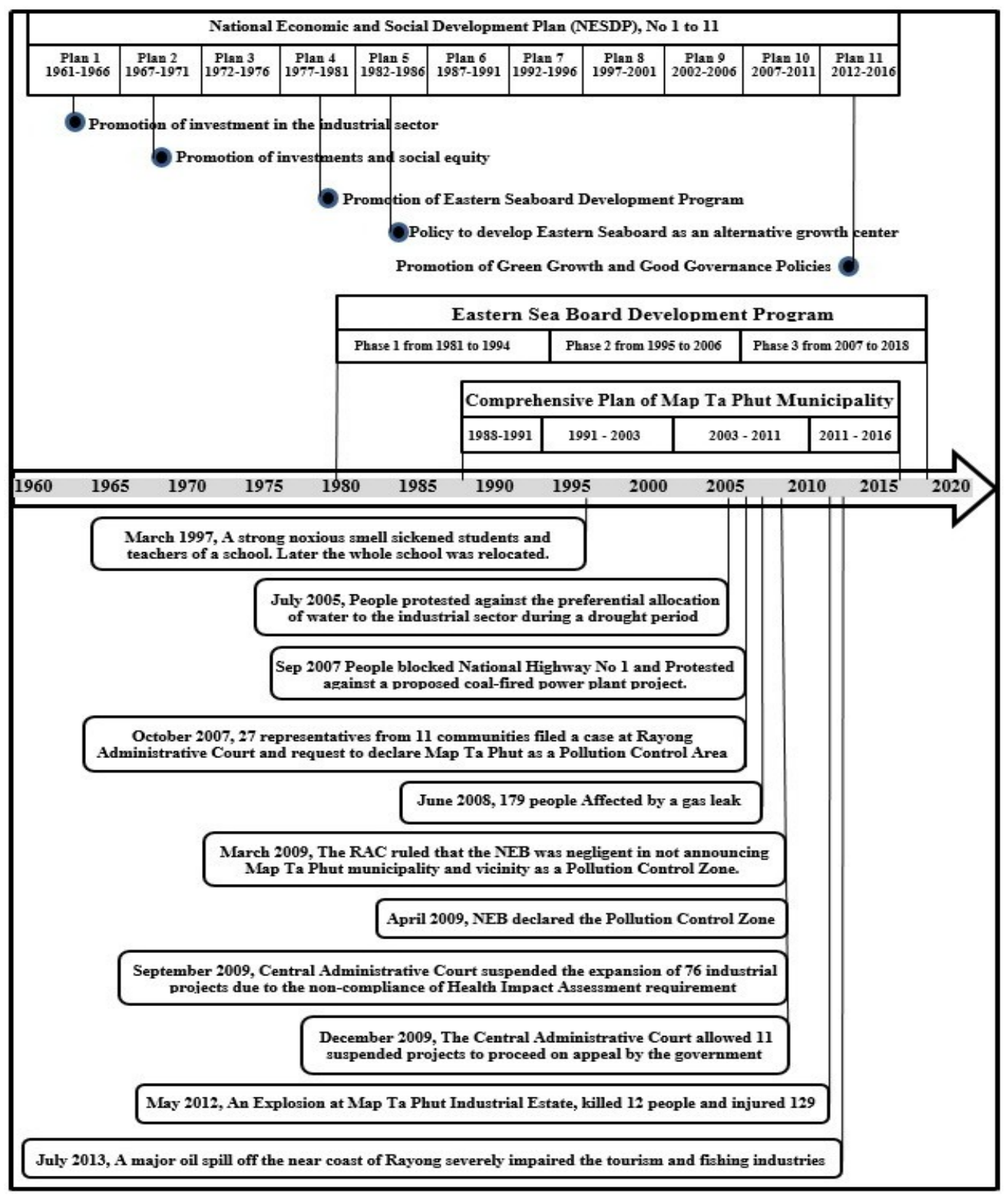

\section{Methodology}

The conflict at Map Ta Phut has been primarily spatial and environmental in its nature. Therefore, our study employed the common spatial analysis tools, Geographic Information System (GIS) and Remote Sensing (RS) images to assess the situation before and after policy intervention.

GIS and RS-based analysis to detect environmental changes and conflict analysis have been widely used in empirical research. For example, Yadav et al. [34] have used these tools to detect the status of ecological corridors and correlate it with human-animal conflicts. Using two sets of Landsat images, covering two decades, and Arc GIS 10 software, this study revealed human interference, urbanization, motorized traffic, noise, and air pollution as reasons for the geographic concentration of conflict points. A similar study integrated an air dispersion model called ISCST3 (Industrial Source Complex Station, Version 3) and GIS software (Arc GIS 8.1) to examine the spatial dispersion patterns of toxic 
substances from industrial sources and associated environmental injustices [35]. The study used two data sets from 1999 and 2000 on air quality, surface and ground water quality for comparison purposes. Therefore, their analysis of change was limited to a short time span. A research study conducted in the Map Ta Phut industrial zone has examined the spatial dispersion of $\mathrm{NO}_{2}$ and $\mathrm{SO}_{2}$ in relation to point sources [36]. This research used a high resolution land cover data set, documenting the status of Map Ta Phut in 2007 and a spatial model called AERMOD (American Meteorological Society-Environmental Protection Agency Regulatory Model). This spatial model was developed by the American Meteorological Society and the U.S. Environmental Protection Agency. Its analysis was limited to the status of Map Ta Phut at the peak of the conflict. Additionally, the analysis was limited to two environmental quality indicators, i.e., $\mathrm{NO}_{2}$ and $\mathrm{SO}_{2}$. Its conclusions were on the performance of the spatial model rather than correlating dispersion and conflict. Similarly, GIS and RS tools have been used for carbon emission management in the Niger Delta [37]. This research has proposed a dispersion model to predict emission levels at any particular location over a vast geographical region.

GIS software (Arc GIS 9.2) has been used to study air pollution levels and the dynamics of their impacts in an attempt to provide information for conflict resolution in a mining region [38]. In this research, GIS was used to predict air quality throughout a region where multiple air quality monitoring stations were not available. Application of GIS and RS tools were also used in resolving conflicts among stakeholders proposing different types of land use. A conflict resolution framework and an awareness building method were outcomes of research based on GIS and a multi-criteria decision analysis technique [39].

In our attempt to use GIS and RS tools for conflict analysis and its resolution, we did not follow a modeling or prediction approach. Instead, we used GIS and RS tools in combination with time series data to detect changes in the environmental status of the study area. Our study used 2007 as the baseline year, because it is the temporal landmark when the conflict at Map Ta Phut turned into a legal battle between the three parties. The temporal span from 2007 to 2012 was considered, since the data was complete, reliable, and up to date. The study area was defined as the Map Ta Phut Municipal area, which generally coincided with the pollution control zone declared by the government (see Figure 3).

GIS software was used as a tool to analyze spatial-environmental changes in the study area. Air and water quality were selected as the environmental quality indicators due to the nature of complaints by civil society stakeholders. Environmental health was not considered as an indicator due to the difficulty of obtaining health data directly attributable to pollution. Air and water quality data, geo-referenced to the study area were obtained from the Pollution Control Department (PCD). The PCD had 6 monitoring stations in and around the industrial zone. These stations have automatic loggers for collecting data on two types of air pollutants. The first type includes air pollutants, such as sulfur dioxide $\left(\mathrm{SO}_{2}\right)$, nitrogen dioxide $\left(\mathrm{NO}_{2}\right)$, carbon monoxide $(\mathrm{CO})$, particulate matter $\left(\mathrm{PM}_{10}\right)$, and ozone $\left(\mathrm{O}_{3}\right)$. The second group consists of VOCs, such as vinyl chloride, butadiene, dichloromethane, and chloroform. Water quality data were also obtained from PCD. In 2007, PCD had 4 monitoring points in the Map Ta Phut industrial zone that could assess surface water quality. They reported water quality using general indicators. These parameters included $\mathrm{pH}$, suspended solids (SS), biological oxygen demand (BOD), chemical oxygen demand (COD), and heavy metals (copper, arsenic, lead, iron/ferrous, and zinc). Due to the administrative court's decision in 2009, the PCD increased the number of monitoring points to 17 and expanded water quality testing to include more indicators. However, the spatial analysis 
related to water pollution of the current study was limited to the heavy metals. This was due to the limited data in the base year. Moreover, water pollution due to heavy metals is more relevant to the environmental conflict.

Time series data of average air quality and water quality indicators for each year from 2007 to 2012 were analyzed to detect changes in environmental conditions after the introduction of policy measures by the government. This was a general analysis to detect trends during that time span. It was followed by a spatial analysis of yearly average data pertaining to air quality and water quality obtained from each monitoring station. Data with geo-references were plotted on a base map obtained from the PCD and analyzed using the Geo-statistical Analysis function of ArcMap ${ }^{\mathrm{TM}} 10$. This analysis was limited to the years 2007 and 2012 in order to determine changes as a result of the government's policy intervention.

It should be noted that the PCD's measurements represent the situations at some pre-determined points. Extrapolating environmental quality from point data to an area was done using the GIS function, Kriging Interpolation, and Overlay by Weight Sum. This is a well-established method in spatial statistics [40,41]. Air and water were considered polluted when spot measurements for the respective indicators exceeded the maximum allowable levels stipulated by the PCD. The multi-criteria spatial data analysis model of Geertman [42] was used to distinguish the polluted spaces in the study area.

\section{Monitoring of the Outcomes of Governmental Policy Interventions}

This section presents the results of spatial-environmental analysis conducted to determine the effects of governmental policy intervention. It is not an assessment, but an inquiry to identify temporal trends related to air and water quality changes.

\subsection{Outcomes on Air Quality Issues}

Raw data for the five air quality indicators showed that the maximum recorded concentrations of each pollutant extremely exceeded maximum permissible levels every year from 2007 to 2012 . Figure 5 shows that the yearly average readings for each air pollution indicator were higher than the respective air quality standards except for carbon monoxide (CO). Only the average level of $\mathrm{PM}_{10}$ showed a significant declining trend. However, $\mathrm{PM}_{10}$ levels still far exceeded the maximum allowable level of $0.05 \mathrm{mg} / \mathrm{m}^{3}$. These findings suggest that there has been little impact on air pollution by governmental policy intervention. However, it should be noted that averaging measurements taken throughout the year from all monitoring stations into a single figure is a weakness of the above trend analysis. It does not explain spatial variation. Therefore, spatial analysis of air quality was conducted using data with geo-references.

Air quality data obtained from the PCD gave the annual average air quality at the measurement points for each indicator. Map layers were produced for the five general air quality indicators. Then, these were overlaid on the base map to scrutinize the composite air quality in 2007 and 2012. Comparison of air quality in 2007 and 2012 with reference to the five general air quality indicators is shown in Figure 6. The GIS-based multi-criteria spatial analysis index used by this study shows the areas with highest concentration of air pollution in white patches and areas with least air pollution in black patches. The location of these patches can be different for each air quality indicator. The degree of whiteness indicates the intensity of the pollution in relation to one or more indicators. 
Figure 5. Average yearly emission levels of general air pollutants.

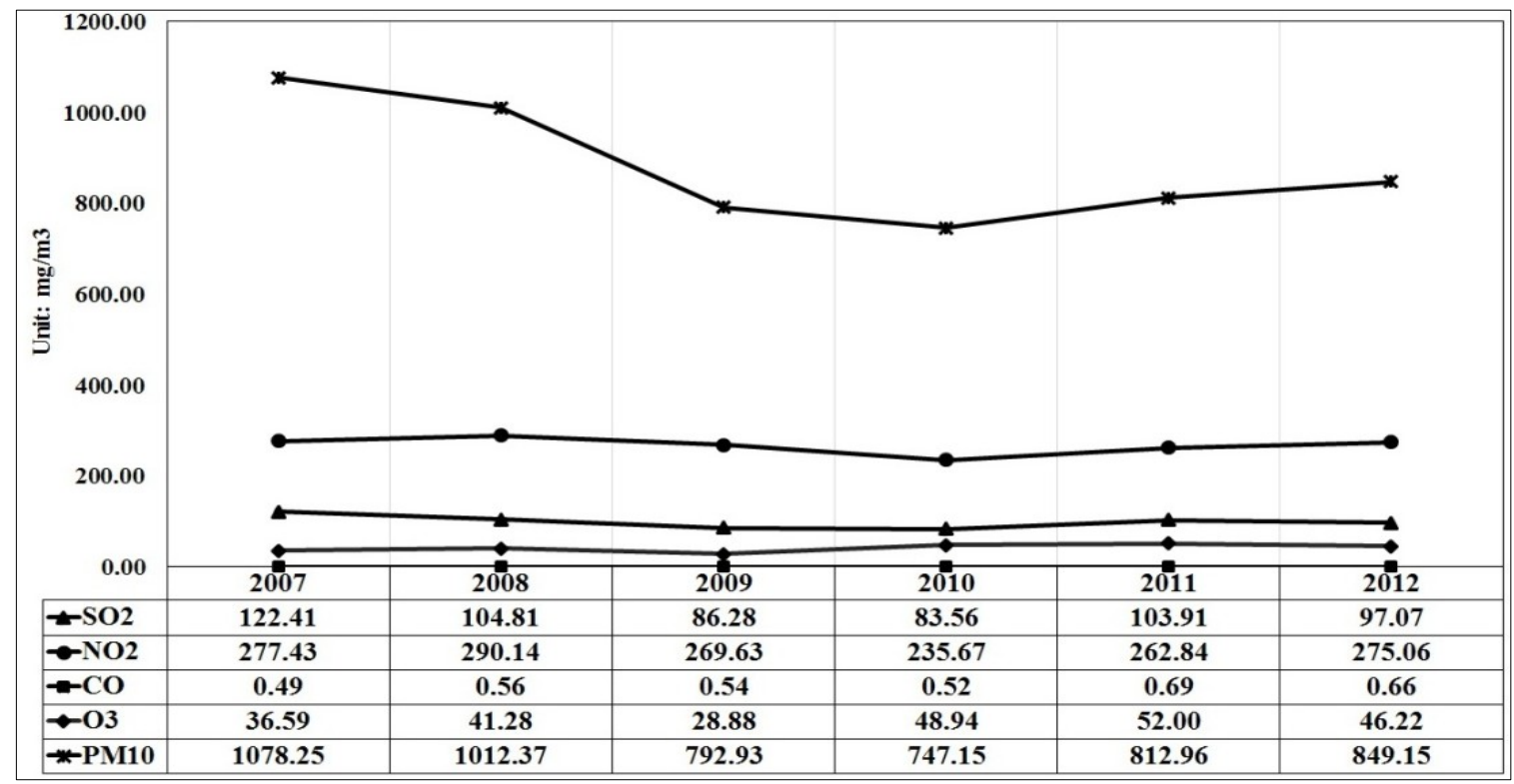

Note: Air quality standard for $\mathrm{SO}_{2} \leq 0.30 \mathrm{mg} / \mathrm{m}^{3} ; \mathrm{NO}_{2} \leq 0.057 \mathrm{mg} / \mathrm{m}^{3} ; \mathrm{CO} \leq 10.26 \mathrm{mg} / \mathrm{m}^{3} ; \mathrm{O}_{3} \leq 0.14 \mathrm{mg} / \mathrm{m}^{3}$; $\mathrm{PM}_{10} \leq 0.05 \mathrm{mg} / \mathrm{m}^{3}$ [43]. Data Source: Pollution Control Department.

Figure 6. Composite spatial distribution pattern of air pollution by $\mathrm{SO}_{2}, \mathrm{NO}_{2}, \mathrm{O}_{3}, \mathrm{CO}$, and $\mathrm{PM}_{10}$ in 2007 and 2012.

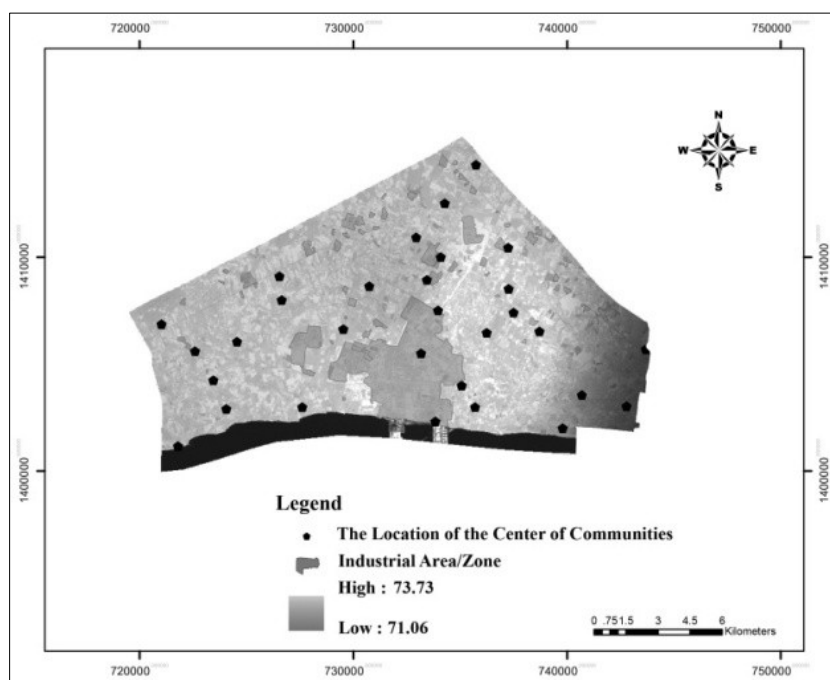

(a) situation in $\mathbf{2 0 0 7}$

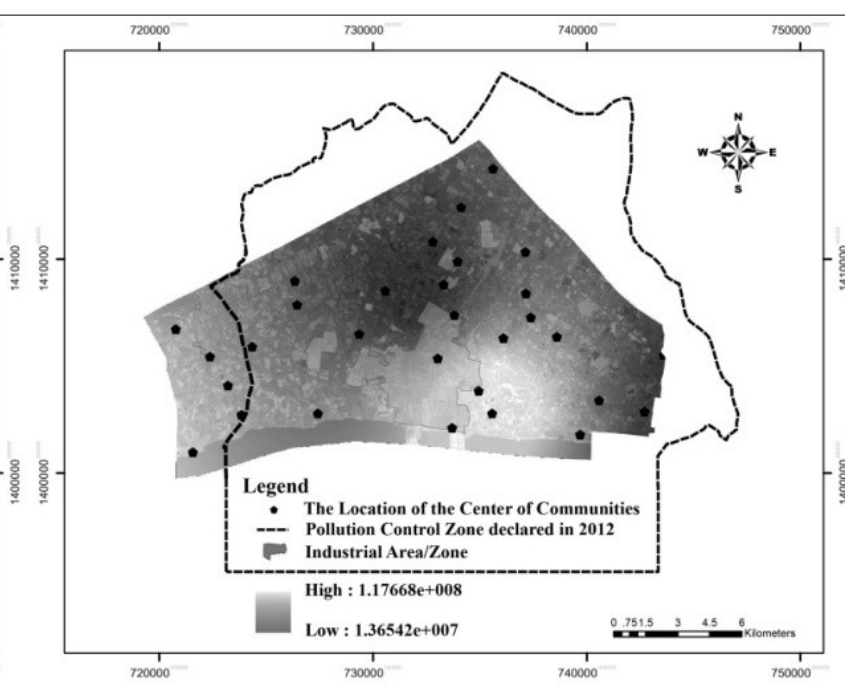

(b) situation in 2012

Data Source: Pollution Control Department.

Figure 6a suggests that the cumulative effect of $\mathrm{SO}_{2}, \mathrm{NO}_{2}, \mathrm{O}_{3}, \mathrm{CO}$, and $\mathrm{PM}_{10}$ pollution was spread all over the Map Ta Phut municipal area in 2007. That explains why people protested against the industries and the government at that time, and requested legal intervention from the Rayong Administrative Court. The figure shows a diffused white patch covering most of the municipal area with a high intensity white patch on the eastern side of the industrial zone. The decreased white area in Figure $6 \mathrm{~b}$ indicates that the concentration of air pollution was limited only to the area east of the Map Ta Phut industrial zone in 2012. That figure also shows that air pollution decreased in most of the municipal area by 2012. This could be attributed to the air pollution control measures imposed by the 
government on industrial plants. However, it should be reiterated that Figure $6 a, b$ indicates the average air pollution status in the respective years when all indicators are considered together. Spatial concentration of individual pollutants can vary during the year due to several factors. These include industries that may emit particular types of pollutants, changes in wind direction, and varying climatic conditions during the year.

In an attempt to determine if VOC emissions decreased since the introduction of governmental policy, the average levels of VOCs in each year from 2007 to 2012 were compared. Figure 7 indicates no significant trend of VOC reduction during this period. Levels of average emission during the years have shown huge fluctuations for the four types of VOCs. The average emissions of chloroform showed an increasing trend during this period.

Figure 7. Average yearly emission levels of VOCs.

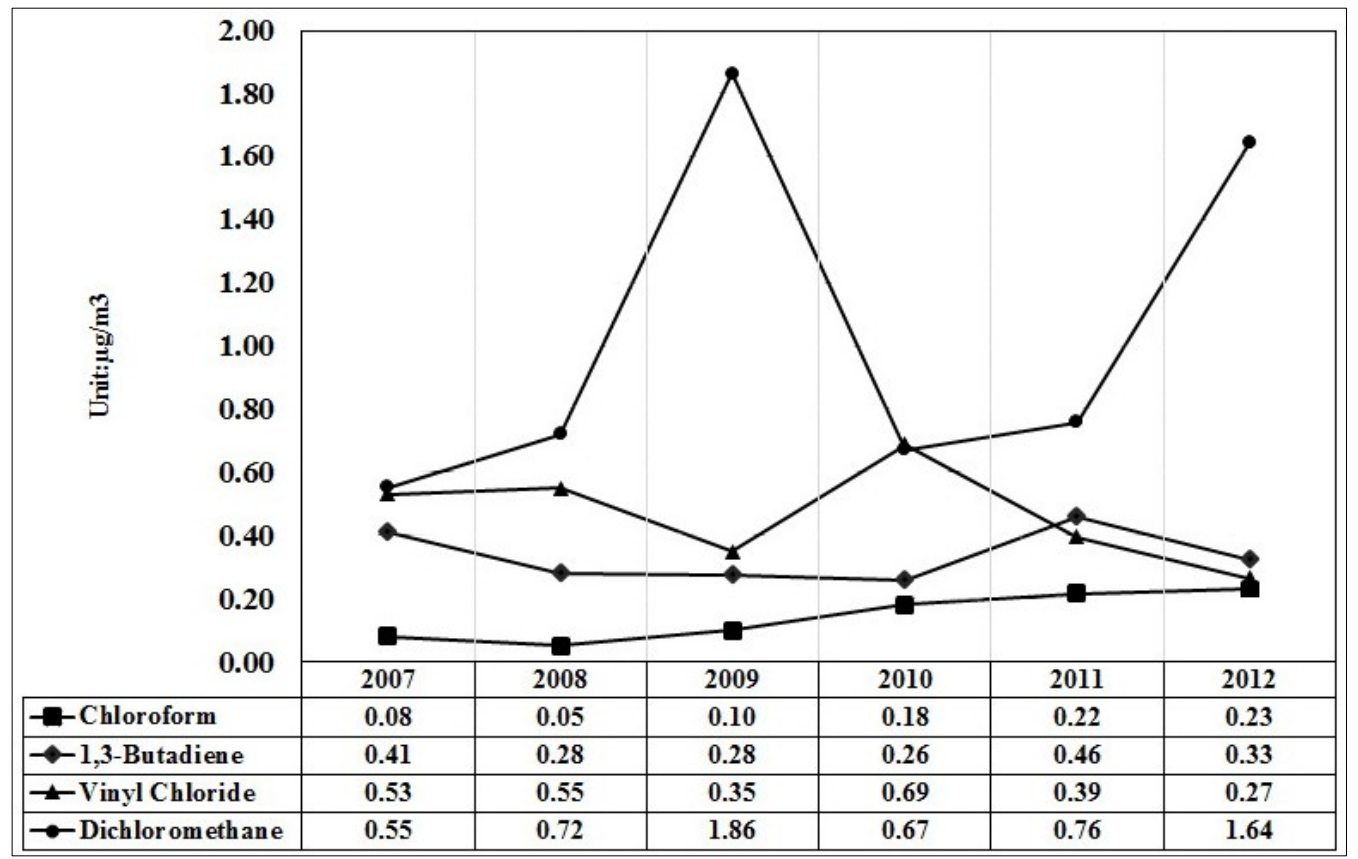

Note: Air quality standard for; vinyl chloride $\leq 10 \mu \mathrm{g} / \mathrm{m}^{3}$, butadiene $\leq 0.33 \mu \mathrm{g} / \mathrm{m}^{3}$, dichloromethane $\leq 22 \mu \mathrm{g} / \mathrm{m}^{3}$, chloroform $\leq 0.43 \mu \mathrm{g} / \mathrm{m}^{3}$. [32]. Data Source: Pollution Control Department.

Spatial analysis conducted to find the concentration of VOCs gave different results. The white patch in Figure 8a shows that air pollution by the four types of VOCs was clearly concentrated in an area north of the Map Ta Phut industrial zone in 2007. Physical checking at the locality indicated that this area matches the location of a small industrial estate. VOCs in this area had disappeared by 2012, as shown in Figure $8 \mathrm{~b}$. This can be attributed to the measures adopted by that industrial estate to eliminate VOC emissions. However, a diffuse white area in Figure $8 \mathrm{~b}$ indicates that pollution by VOCs had become a problem in other areas of the Map Ta Phut Municipality by 2012. Although the white patch in Figure $8 \mathrm{~b}$ is light and diffuse, indicating a lower concentration of air pollution by VOCs, the spread of pollution throughout the municipality poses a grave situation. This is because VOCs present more health risks than other air pollutants $[24,44]$. 
Figure 8. Composite spatial distribution pattern of air pollution by Volatile Organic Compounds (VOCs) in 2007 and 2012.

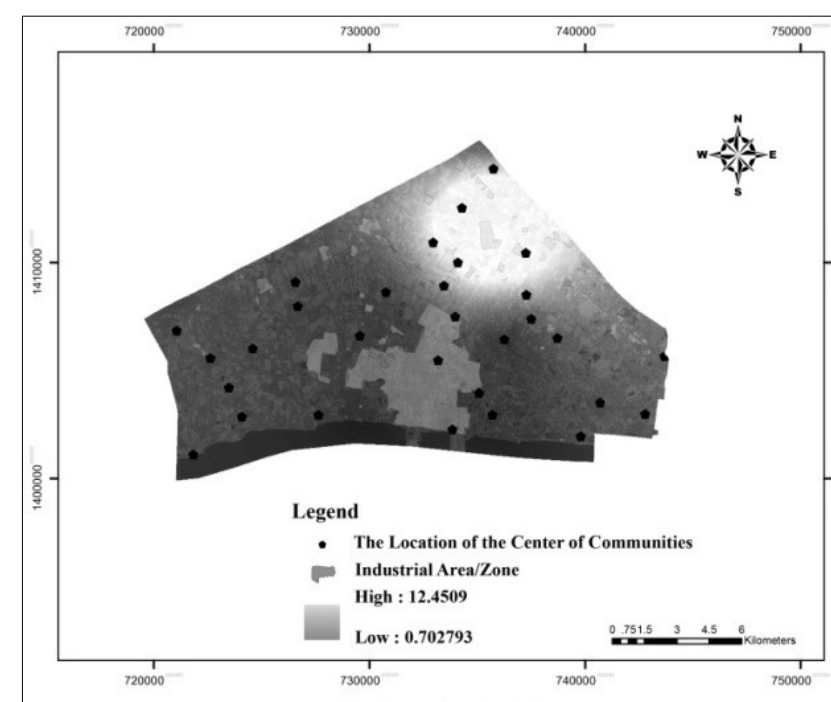

(a) situation in $\mathbf{2 0 0 7}$

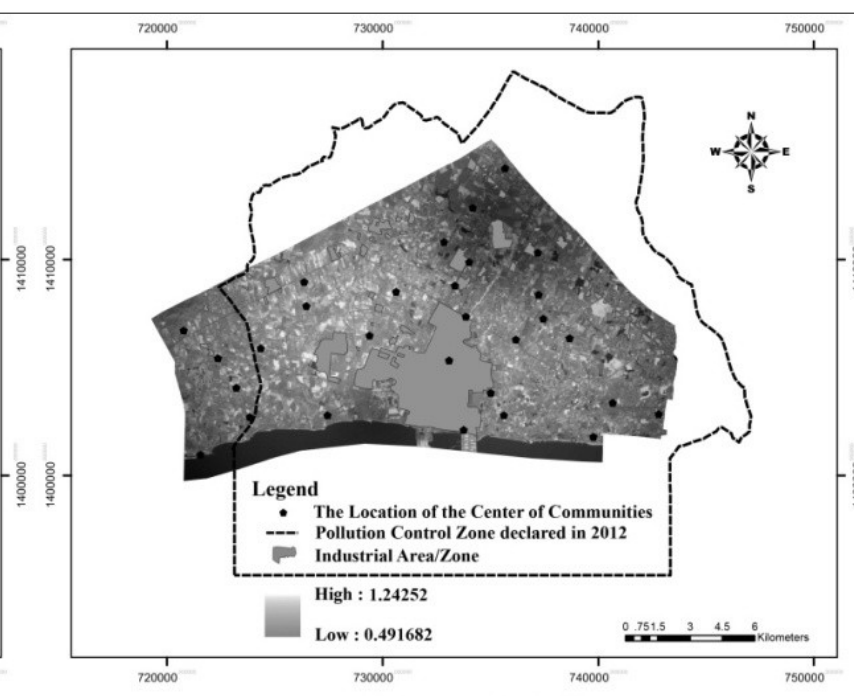

(b) situation in 2012

Data Source: Pollution Control Department.

It should be noted that the yearly average VOC emissions remained within their respective air quality standards during the whole period, except in 2011 for butadiene levels. Does that mean that assuming that VOCs are the main health risk in Map Ta Phut is unfounded? The real risk is accidental release of high quantities of VOCs to the ambient air. People detect such releases due to the aromatic nature of some VOCs and worry about the health risks. The average monthly measurements by the PCD revealed that the levels of benzene and dichloromethane exceeded the maximum amount at most of the monitoring stations during 2007-2010 [45]. The average monthly level of butadiene fluctuated below and above the standard during the same period. The problem of occasional increase in VOC emissions can be resolved if the industrial plants implement technological and safety measures as well as comply with the requirements of the PCD. Pollution concentration mapping is a useful tool to identify the point sources that occasionally emit VOCs and implement tailor-made emission control measures.

\subsection{Outcomes on Water Quality Issues}

Average levels of water pollutants in each year from 2007 to 2012 were compared to determine if the quality of surface water has changed since the introduction of governmental policy measures. Figure 9 shows that the amount of heavy metals present in surface water far exceeded the allowable maximum levels for those heavy metals. The concentration of Fe showed a declining trend since 2010. However, the $\mathrm{Zn}$ concentration showed an alarmingly increasing trend. Figure 9 gives the impression that the presence of $\mathrm{As}$ and $\mathrm{Pb}$ in surface water remains more or less the same. However, the raw data given below the graph indicate that their presence remain above the maximum allowed limits of the PCD. The level of $\mathrm{Cu}$ fluctuated around the standard level during 2009-2012. The above discussion implies that the average quality of surface water has not improved in the Map Ta Phut municipal area despite policy interventions by the government. 
Figure 9. Average yearly levels of heavy metals found in surface water bodies of Map Ta Phut.

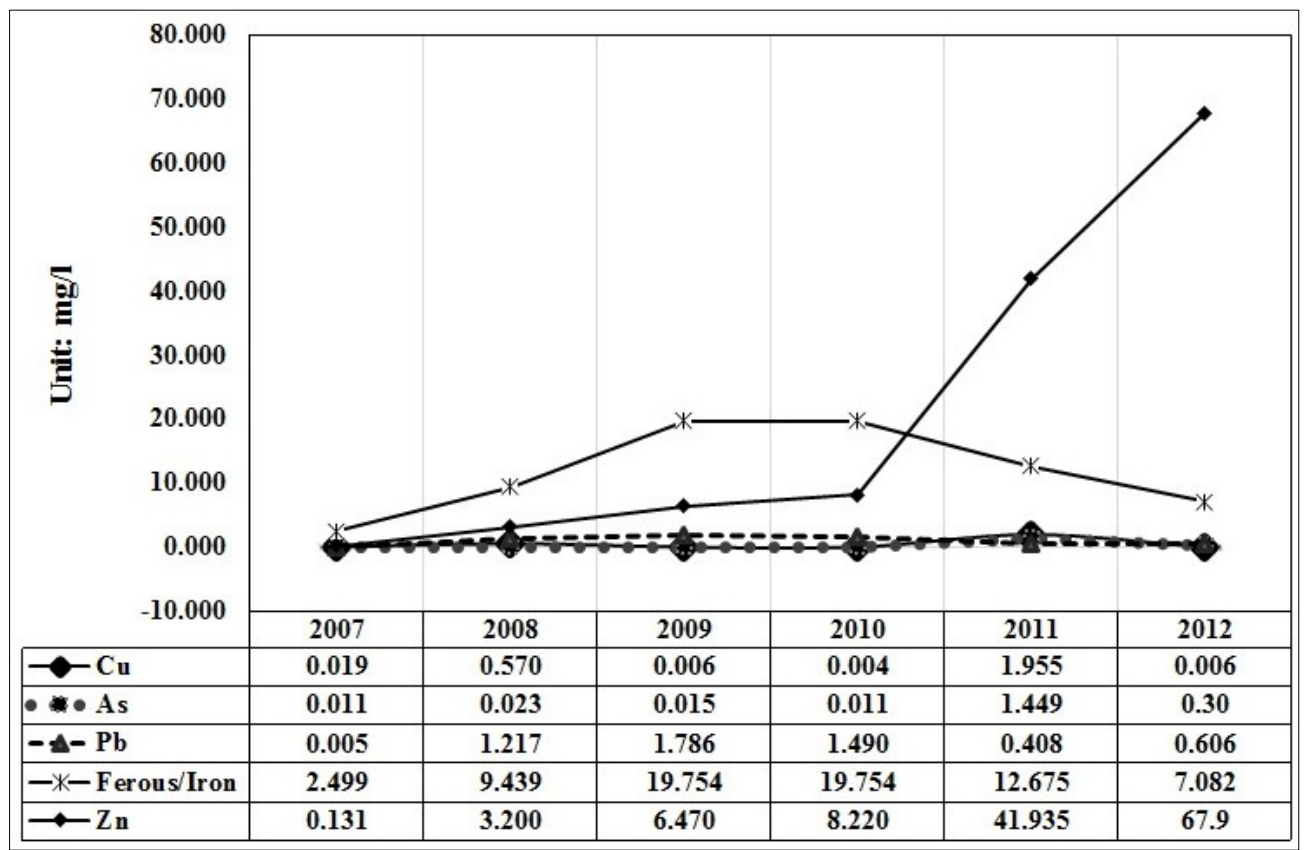

Note: Surface water quality standard for; $\mathrm{Cu} \leq 0.1 \mathrm{mg} / \mathrm{L}, \mathrm{As} \leq 0.01 \mathrm{mg} / \mathrm{L}, \mathrm{Pb} \leq 0.05 \mathrm{mg} / \mathrm{L}, \mathrm{Fe} \leq 0.3 \mathrm{mg} / \mathrm{L}$, $\mathrm{Zn} \leq 1 \mathrm{mg} / \mathrm{l}$. [46]. Data Source: Pollution Control Department.

Spatial analysis of water pollution was conducted using the water quality measurements taken by the PCD from surface water bodies. There was a discrepancy in yearly average data available for the selected water quality indicators $\mathrm{Cu}, \mathrm{As}, \mathrm{Pb}, \mathrm{Fe}$, and $\mathrm{Zn}$. PCD had only 4 monitoring stations in Map Ta Phut in 2007. Therefore, it was not possible to conduct a complete spatial analysis of 2007 water quality. As a result, the spatial analysis shown in Figure 10a is incomplete. Available data for each water quality indicator were plotted on different layers and overlaid on a base map to obtain a composite map. Spatial analysis of water pollution used the Fuzzy overlay and weight sum functions of Arcview $^{\mathrm{TM}}$. The spatial pattern of the composite water pollution by $\mathrm{Cu}, \mathrm{As}, \mathrm{Pb}, \mathrm{Fe}$, and $\mathrm{Zn}$ in 2007 is shown in Figure 10a. The figure shows two big white patches to the west and north-west and three small white patches to the east and northeast of the Map Ta Phut industrial zone. The patches of white indicate the locations of most polluted surface water, while the patches of black indicate the locations with least/not polluted surface water. These locations are mostly outside the industrial zone, as expected.

The likelihood of water pollution within the industrial zone is slim according to the industrialists, because each factory has primary wastewater treatment facilities, which are linked to one of the three central waste water treatment facilities. The IEAT requires each industrial plant to pre-treat their wastewater before sending to a central treatment facility for final treatment [47]. It is presumed that surface water pollution noted in some locations is due to illegal discharge of partially/untreated wastewater to surface water bodies, such as canals and rivers. The white patch on the western side of Figure 10a corresponds with some local canals. Figure 10a also indicates that 8 communities are located in the area with worst polluted surface water bodies (indicated by black dots). 
Figure 10. Composite spatial distribution pattern of water pollution by $\mathrm{Cu}, \mathrm{As}, \mathrm{Pb}, \mathrm{Fe}, \mathrm{Zn}$ in 2007 and 2012.

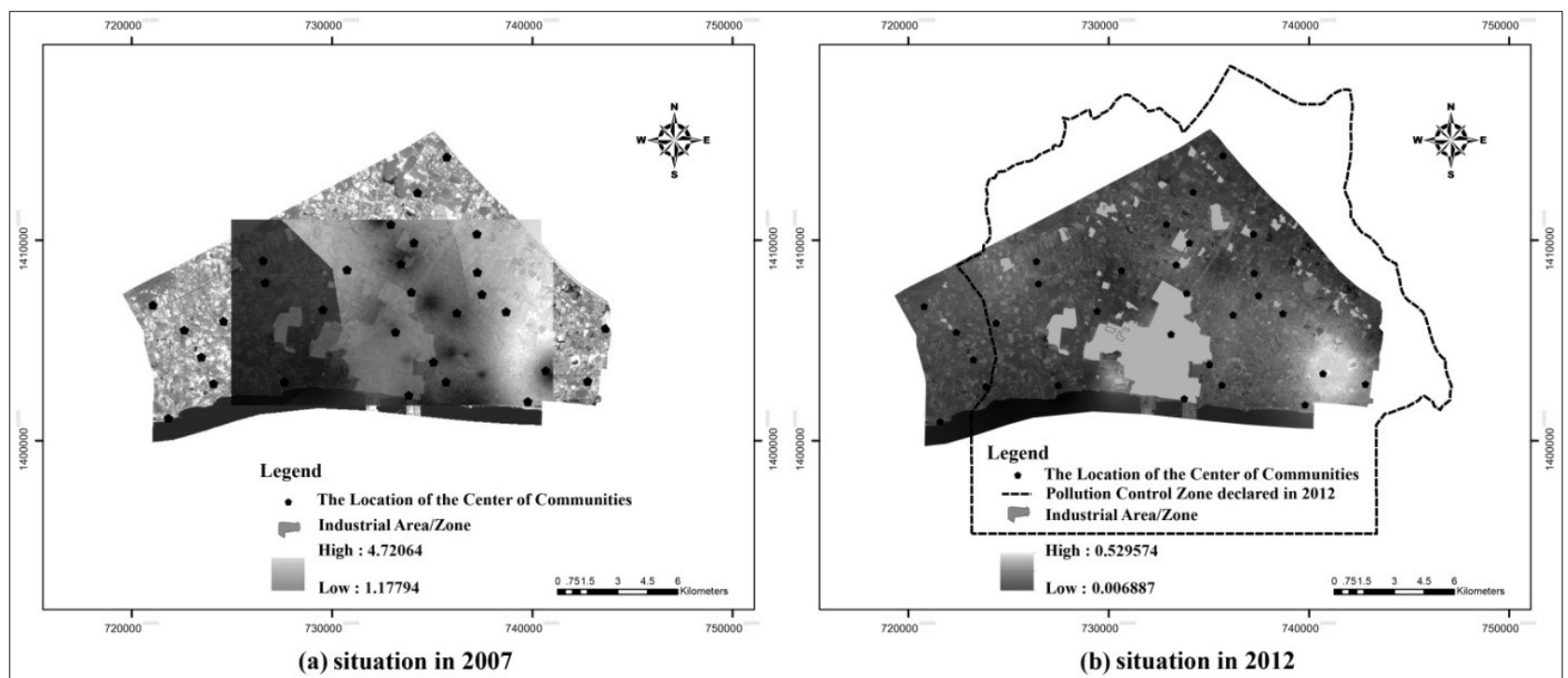

Data Source: Pollution Control Department.

A more complete status of water pollution is available for 2012 due to the addition of 13 water quality monitoring stations, bringing the total number to 17 . They monitor water quality of both surface water bodies and shallow wells. Figure $10 \mathrm{~b}$ shows the composite spatial distribution of water pollution by $\mathrm{Cu}, \mathrm{As}, \mathrm{Pb}, \mathrm{Fe}$, and $\mathrm{Zn}$ in 2012. It shows that the white patches noted in the 2007 map had disappeared by 2012, indicating elimination of most water pollution problems outside the Map Ta Phut industrial zone. However, water pollution within the industrial zone had apparently intensified, as indicated by a large white patch in Figure 10b. This means that the water pollution by heavy metals had been contained to a limited area within the industrial zone. It is an improvement compared to the situation in 2007. Figure $10 \mathrm{~b}$ shows that there are four communities bordering the white patch. That explains why some people continue to complain about water pollution and water related health problems. Water pollution had also intensified in a stretch of the near shore bordering the industrial zone. This situation poses a serious problem. It should be noted that water quality data related to sea water was excluded from the spatial analysis due to the possibility of distorting surface water quality data. Therefore, the dispersion of any water pollution in the sea is not indicated in Figure 10. The inclusion of the part of near shore in the pollution control zone is an indication of the vulnerability of sea water for industrial pollution.

Unabated water pollution is a major issue for the government to handle in the years to come, because water pollution is directly related to skin diseases. According to Vichit-Vadakan [48], the complaints of the community members are not only about the polluted surface water bodies, such as canals, but also about polluted shallow wells. Illegal dumping of industrial waste on canal banks and vacant lands is one of the reasons for polluted surface water and ground water. Some people have indicated that their agricultural livelihoods were severely affected due to the unsuitability of surface and ground water for agricultural purposes. There were no data pertaining to 2007 to substantiate these claims. 


\section{Discussion}

The spatial and trend analyses presented in Section 4 imply that the Pollution Mitigation and Elimination Action Plan and associated strategies have been only partially effective in bringing some environmental improvements to the Map Ta Phut municipal area. Although the general air quality has not significantly improved, as indicated in Figure 8, the emission of VOCs seem to meet newly introduced standards in 2012. This means that one major concern for public health has been eliminated. However, water pollution by heavy metals remains a critical and unresolved problem in spite of its containment to a limited area of the municipality. A surprising finding of this study is a trend in declining cases of pollution-related diseases in the broader context of Map Ta Phut municipal area. More comprehensive research is needed to determine whether this trend can be attributed to the government's policy interventions since 2009.

Only 2-3 years have passed since the implementation of the government's policy interventions. It is not possible to expect significant changes within such a short period of time. On the other hand, the Pollution Mitigation and Elimination Action Plan aimed to improve water and air quality to an acceptable level within one year. The plan implementation has not successfully achieved that goal. What could be the reasons for the shortcomings?

Although the government introduced several new regulations and standards to curb pollution after the court rulings, it is doubtful that the government strictly imposed those new command and control measures. Some environmentalists are skeptical about the government's commitment to enforcement and hence any significant change of the environmental status of Map Ta Phut resulting from the new EMM (Environmental Management Measures). They question the need of new laws when the existing ones are not seriously enforced. They doubt that the government will take a tougher policy stance towards the investors, fearing threats by investors to relocate their plants elsewhere. The state is more concerned with economic consequences, such as loss of investments, income, and jobs. The government's appeal against the court rulings was an indication of its continued support for new investments in spite of strong public sentiments against any further industrial expansion in Map Ta Phut. Does that mean that the government is not seriously pursuing its sustainable development policy towards green growth? The improving trend of environmental indicators since the introduction of new policy measures in 2009 and onward suggest that the government was optimistic about redirecting industrial development in Map Ta Phut towards the path of green growth.

As a part of the agreement for conflict resolution, the private sector enterprises have agreed to emission reduction and pollution control, as well as to maintain a Pollutant Release and Transfer Register (PRTR) [49]. The concept of a PRTR was one of the outcomes of the UN Conference on Environment and Development (UNCED) held in Rio de Janeiro in 1992. Research has revealed the usefulness of PRTR to both private and public sectors to clarify environmental status to the society. About $60 \%$ of the research respondents (jury) have been in affirmation of its usefulness. However, the rest have expressed pessimism about the usefulness of such information to the general public [49].

It is also not very clear whether the industrialists comply with the new command and control measures. A research study has revealed that despite the strict enforcement of the command and control measures of the Environmental Quality Act of 1992 to control emissions in Map Ta Phut, large amounts of toxic substances and pollutants continued to be released by various industrial plants. This 
research opined that a two-pronged approach consisting of: (1) investment in pollution abatement technology, and (2) allowing people to express their dissatisfaction through non-violent means until they feel confident that the government's new policy measures work in their favor [50]. Apparently many people have voiced dissatisfaction with the government's policy measures. This was especially true of enforcement of EIA and HIA recommendations. People view them as mere documents to approve projects that are not seriously monitored for emissions that cause damage to the environment and human health [51].

In parallel to the private sector's PRTR, the state sector, through the Pollution Control Department, should stringently measure air quality using its monitoring stations and publish selected information on its website on a regular basis. It should also publicize the overall air quality using the air quality index at two places on electronic billboards. It is uncertain how civil society stakeholders will know that air quality is improving and the risks to their respective localities are decreasing. The results of a stakeholder centered research have recommended that the PCD should gather information about potential audiences for external communication. It should then provide information to them for which there is supporting scientific evidence. This research has also opined that it would be a mistake for the PCD to deal with only local leaders in their external communication approach for conflict resolution. Instead PCD should provide information to the society in general in a comprehensible manner and request their feedback [52].

Better access to information can safeguard people from the impacts of pollution to a certain extent. Under the Official Information Act of 2010, state agencies are required to make environmental and health information publicly available. This includes information on pollutants, their health impacts, and efforts to monitor and resolve environmental health issues caused by industrial sources. However, research conducted by the Access Initiative and the Thailand Environment Institute has revealed that requests by some communities for: (1) a list of factories in the Map Ta Phut industrial zone that fail to adhere to the government's air and water quality standards, (2) a list of pollutants that factories release into the air and water, and (3) information about the health impacts associated with the pollutants released, have not been forthcoming from authorities. Even if information is available to the public, ordinary people are unlikely to fully comprehend such information. It is from that perspective that researchers consider pollution concentration mapping, as demonstrated in the current study, a more effective way of providing information to the public. This is because ordinary people can easily comprehend problematic locations in relation to their communities. This paper argues that spatial tools, such as environmental quality maps, are more comprehensible to people than sophisticated air quality indices.

Although it is questionable whether better access to information alone can protect people from pollution, the government has to improve access to information if it is serious about enhancing the community's continuous participation in the monitoring and inspecting of environmental quality and the generation of pollution at the source, as stipulated in the Pollution Mitigation and Elimination Action Plan. Otherwise, the mistrust between the civil society, industries, and the government will contribute to perpetuate the environmental conflict at Map Ta Phut. 


\section{Conclusions}

The first half of this paper presented the chronological evolution of the environmental conflict at the Map Ta Phut industrial area. It showed that the conflict emerged due to the expansion of the industrial zone into community areas in violation of land-use planning and zoning regulations. By letting the industries infringe upon the green buffer zone, the government allowed negative environmental externalities of industries to spill over to the communities. In other words, the government allowed the conflict to emerge by neglecting to act. Instead of playing its role as a regulator, the government let market forces decide how land should be developed in Map Ta Phut. In doing so, the government clearly favored the industrialist lobby and jeopardized the environmental well-being of society. The government has failed in its duty as a regulator to guide industrial expansion in Map Ta Phut in a sustainable manner, balancing the economic, social, and environmental interests of all three stakeholder groups.

Industrialization should be based on a thoroughly worked out and strategized development plan. The chronological progression of the environmental conflict at Map Ta Phut shows industrializing countries that even a planned industrial development can lead to catastrophe when the parties responsible for implementing that plan fail to fulfill their mandate. As the Thai government recognized later, non-compliance with laws, rules and regulations was the cause for losing public trust, leading to an impasse between the state, society, and industry stakeholders. Most importantly, policy and regulatory lapses by the government and non-compliance of the regulatory norms by the industrialists were reasons for the pollution loads to exceed the carrying capacity of the coastal ecosystem where Map Ta Phut industrial zone is located. Investors do not come to invest in countries with strict regulations, especially environmental regulations. In the case of Map Ta Phut, the government introduced critical control measures only after exceeding the carrying capacity of the ecosystem. This resulted in incurring immense environmental and social costs. Should the newly industrializing countries be lenient for the sake of economic growth? Are the economic gains worth considering the social and environmental costs? There was no evidence of financial sanctions, such as fines and penalties, levied on industries for violating planning and environmental regulations. The Map Ta Phut case exemplified that the governments of industrializing countries that offer financial and other incentives to attract investors should also insist that investors internalize responsibility for pollution control as a counter balance. In simple terms this means that investors absorb the cost of cleaning up any pollution (i.e., the polluter pays principle) so that environmental consequences of industrialization do not exceed the carrying capacity of the ecosystem. In order to relate this idea to policy measures, the planners and managers of new industrial zones should predetermine the carrying capacity of the ecosystems that will undergo urbanization and industrialization.

The case of Map Ta Phut also gives some lessons on conflict resolution for newly industrializing countries. The chronological progression of the conflict shows that the government ignored civil society actions and protests until people sought intervention by the courts. In some countries, there has been violent suppression of society to safeguard the investors in the name of national economic interests. The second part of the paper probed whether the government's pragmatic solutions were effective enough for conflict resolution. The findings imply that the government has been somewhat successful in redirecting the industrial development in Map Ta Phut towards the new policy path of 
green growth and thereby sustainable development, while appeasing the industrial and society stakeholders. According to TKI, the government has apparently used collaborating and compromising modes of conflict resolution, arguably leading to win-win solutions [12]. The compromises on land-use zoning and emission standards, and tailor-made public health service provision to reduce the anxiety of neighboring residents are some ideas that newly industrializing countries can proactively consider. However, only time will reveal to what extent the government's pragmatic solutions can bring lasting resolution to the environmental conflict at Map Ta Phut and redirect industrial development from its currently unsustainable state towards one of green growth.

\section{Acknowledgments}

The authors are thankful for the Cooperative Research Network of the Commission on Higher Education, Ministry of Education, Thailand, for providing financial support to conduct this research.

\section{Author Contributions}

The first author was solely responsible for data collection from primary and secondary sources and analyze them using the software mentioned in the paper. Both authors jointly conceptualized and structured the paper. Data processing was done by the first author under the direction of the second author for writing Section 5. The whole paper was jointly drafted and developed by two authors to bring to the current state.

\section{Conflicts of Interest}

The authors declare no conflicts of interest.

\section{References}

1. United Nations-Economic and Social Council. World Economic and Social Survey 2011: The Great Green Technological Transformation. Available online: http://www.un.org/en/development/ desa/policy/wess/wess_current/2011wess.pdf (accessed on 2 April 2013).

2. United Nations Environment Program-Regional Office for Asia and Pacific. Summary for Asia and the Pacific Region on the Eve of Rio+20. Available online: http:/www.unep.org/ geo/pdfs/geo5/RS_AsiaPacific_en.pdf (accessed on 25 July 2013).

3. Hardoy, J.E.; Mitlin, D.; Satterthwaite, D. Environmental Problems in an Urbanizing World; Earthscan Publications: London, UK, 2001.

4. Fleig, A.K. ECO-Industrial Parks: A Strategy towards Industrial Ecology in Developing and Newly Industrialised Countries. Available online: http://www2.gtz.de/wbf/library/detail.asp? number $=390$ (accessed on 21 June 2013).

5. Thailand Environment Institute. Knowledge Forum for Map Ta Phut 1: The State of Pollution, Health and Urban Planning; Thailand Environment Institute: Bangkok, Thailand, 2011.

6. Jerve, A.; Nissanke, M. Aid Effectiveness to Infrastructure: A Comparative Study of East Asia and Sub-Saharan Africa. Available online: http://jica-ri.jica.go.jp/IFIC_and_JBICI-Studies/jica-ri/ english/research/archives/jbic/infra/index.html (accessed on 27 June 2012). 
7. Hassarungsee, R.; Kiatiprajuk, S. Time to Rethink Industrial Development; Chulalongkorn Social Research Institute: Bangkok, Thailand, 2010.

8. Osaka, H. Map Ta Phut: Thailand's Minamata. Available online: http://www.hurights.or.jp/ archives/focus/section2/2012/06/map-ta-phut-thailands-minamata.html (accessed on 25 June 2013).

9. Coser, L. The Functions of Social Conflict. Available online: http://www.colorado.edu/conflict/ peace/example/coser.htm (accessed on 25 June 2013).

10. Bercovitch, J.; Kremenyuk, V.; Zartman, I.W. The SAGE Handbook of Conflict Resolution; Sage Publishers: New York, NY, USA, 2008.

11. Mack, R.W.; Snyder, R.C. The Analysis of Social Conflict: Toward an Overview and Synthesis. J. Confl. Resolut. 1957, 2, 212-248.

12. Thomas, K.W.; Kilmann, R.H. Thomas-Kilmann Conflict Mode Instrument. Available online: https://www.cpp.com/pdfs/smp248248.pdf (accessed on 15 February 2014).

13. GTZ-FRCS Project Team. Practioners's Guide: Conflict Analysis. Available online: http://www. google.com.hk/url? sa=t\&rct=j\&q=\&esrc=s\&source=web\&cd=1\&ved=0CCkQFjAA\&url=http $\% 3$ A\%2F\%2Fwww.methodfinder.net $\% 2$ Fdownload_all.html\%3Ffile $\% 3$ Dfiles $\% 2$ Fdocuments $\% 2 \mathrm{Fm}$ ethods_examples\%2F0059\%2520-\%2520Conflict\%2520Analysis\%2520-\%2520Method.pdf\&ei= YG9UU_jAGKmtsQTQnIDYBw\&usg=AFQjCNEMwQIoQuSse15tmr8XZYJ7Tsw3Pg\&bvm=b v.65058239,d.cWc\&cad=rjt (accessed on 15 February 2014).

14. Tsuneishi, T. The Regional Development Policy of Thailand and Its Economic Cooperation with Neighbouring Countries. Available online: http://www.ide.go.jp/English/Publish/Download/ Dp/032.html (accessed on 1 March 2008).

15. Industrial Estate Authority of Thailand. Roles \& Responsibilities. Available online: http://www.ieat.go.th/ieat/index.php/en/about-en/roles-responsibilities (accessed on 1 August 2013).

16. Japan International Corporation Agency_Overseas Economic Corporation Fund. Eastern Seaboard Development Program. Available online: http://www.jica.go.jp/english/our_work/evaluation/ reports/2000/pdf/2001_0420.pdf (accessed on 5 August 2013).

17. Office of the National Economic and Social Development Board. Gross Domestic Product: Q2/2012. Available online: http://eng.nesdb.go.th/Portals/0/eco_datas/account/qgdp/data2_12/ detail_Eng.pdf (accessed on 11 June 2013).

18. Berke, P.R.; Godshalk, D.R. Urban Land Use Planning; University of Illinois Press: Chicago, IL, USA, 2006.

19. Atchasai, S. Urban Planning in Thailand: Good Governance for Sustainable Development. Available online: http://www.tei.or.th/event/090303-maptapud-brochure.pdf (accessed on 20 August 2013). (In Thai)

20. ThaiPublica. 30 Year Eastern Seaboard Development Project and Sustainable Development. Available online: http://thaipublica.org/2012/11/30-years-eastern-seaboard-development (accessed on 10 March 2012). (In Thai)

21. Department of Public Works \& Town and Country Planning. Comprehensive Plan for Map Ta Phut Municipality; Department of Public Works and Town \& Country Planning: Bangkok, Thailand, 2011. (In Thai) 
22. The Government Public Relations Department. The Solving of Environmental Problems at Map Ta Phut in Rayong. Available online: http://thailand.prd.go.th/view_news.php?id=4604\&a=2 (accessed on 25 July 2013).

23. Buakamsri, T.; Larson, D.; Hnnarong, F.; Saetang, P.; Moksuwan, W. Greenpeace, Thailand's Air Poison Cocktail. Available online: http://www.greenpeace.org/seasia/th/Global/seasia/report/ 2008/2/map-ta-phut-air-analysis.pdf (accessed on 25 July 2013).

24. Tanyanont, W.; Vichit-Vadakan, N. Exposure to Volatile Organic Compounds and Health Risks among Residents in an Area Affected by a Petrochemical Complex in Rayong, Thailand. Available online: http://www.tm.mahidol.ac.th/seameo/2012-43-1/25-5051.pdf (accessed on 30 July 2013).

25. Asian Correspondent. The environmental problems at Map Ta Phut. Available online: http://asiancorrespondent.com/26595/the-environmental-problems-at-map-ta-phut/ (accessed on 11 July 2013).

26. Health Information System Office. Map Ta Phut: A Hot Economic Issue for the Nation, A Pollution Problem for Local communities. Available online: http:/www.hiso.or.th/hiso/ picture/reportHealth/ThaiHealth2010/eng2010_16.pdf (accessed on 21 August 2013).

27. Chulasirii, M. Speicific Environmental Health Concerns in Thailand: Focusing on Map Ta Phut Industrial Estate. Available online http://www.qscience.com/doi/abs/10.5339/qproc.2012.mutagens. 3.13 (accessed on 2 August 2013).

28. Fuller, T. In Industrial Thailand Health and Business Concerns Collide. Available online: http://www.nytimes.com/2009/12/19/world/asia/19thai.html?pagewanted=all (accessed on 18 December 2012).

29. Hariharan, M. Thailand's Map Ta Phut crisis - The NGO side of the story. Available online: http://www.icis.com/blogs/asian-chemical-connections/2010/03/thailands-map-ta-phut-crisis/ \#sthash.ztAZtWdS.dpuf (accessed on 18 December 2012).

30. Kovidhavanij, W. Map Ta Phut, Industry and Environment: Challenge of Sustainable Development. Available online: http://www.asianews.it/news-en/Map-Ta-Phut,-industry-andenvironment:-challenge-of-sustainable-development-26002.html (accessed on 27 June 2013).

31. Sustainable Development Foundation and Social Research Institute. Planning on Pollution Mitigation and Elimination in the Rayong Area, B.E. 2550-2554 (2007-2011); Sustainable Development Foundation and Social Research Institute, Chulalongkorn University: Bangkok, Thailand, 2011.

32. Royal Thai Government. Report of the Committee on Solving Problems at Map Ta Phut Meeting 2/2553. Available online: http://www.thaigov.go.th/en/news-room/item/60750-report-of-thecommittee-on-solving-problems-at-map-ta-phut-meeting-2/2553.html (accessed on 15 July 2013).

33. Sarnsamak, P. Strict Regulations Needed to Protect map Ta Phut Environment: NHC. Available online: http://www.nationmultimedia.com/2011/04/23/national/Strict-regulations-neededto-protect-Map-Ta-Phut-e-30153751.html (accessed on 25 July 2013).

34. Yadav, P.K.; Kapoor, M.; Sarma, K. Land Use Land Cover mapping, Change Detection and Conflict Analysis of Nagzira-Navegaon Corridor, Central India Using Geospatial Technology. Int. J. Remote Sens. GIS 2012, 2, 90-98. 
35. Fisher, J.B.; Kelly, M.; Romm, J. Scales of Environmental Justice: Combining GIS and Spatial Analysis for Air Toxics in West Oakland, California. Health Place 2006, 12, 701-714.

36. Chusai, C.; Manomaiphiboon, K.; Saiyasitpanich, P.; Thepanondh, $\mathrm{S} . \mathrm{NO}_{2}$ and $\mathrm{SO}_{2}$ dispersion Modeling and Relative Roles of Emission Sources over Map Ta Phut Industrial Area, Thaialnd. J. Air Waste Manag. Assoc. 2012, 62, 932-945.

37. Fagbeja, M. Applying Remote Sensing and GIS Techniques to Air Quality and Carbon Management: A Case Study of Gas Flaring in the Niger Delta. Available online: http://s3.amazonaws.com/zanran_storage/www.uwe.ac.uk/ContentPages/604517398.pdf (accessed on 2 June 2013).

38. Chitade, A.; Katiyar, S.K. GIS to Predict Air Pollution Level in Mining Region. Available online: http://www.geospatialworld.net/paper/application/ArticleView.aspx?aid=25263 (accessed on 29 January 2014).

39. Zhang, Y.J.; Li, A.J.; Fung, T. Using GIS and Multi-Criteria Decision Analysis for Conflict Resolution in Land Use Planning. Proced. Environ. Sci. 2012, 13, 2264-2273.

40. Oliver, M.A.; Webster, R. Kriging: A Method of Interpolation for Geographical Information Systems. Int. J. Geogr. Inform. Sci. 1990, 4, 313-332.

41. Bayraktar, H.; Turalioglu, F.S. A Kriging-based approach for locating a sampling site. Stoch. Environ. Res. Risk Assess. 2005, 19, 301-305.

42. Geertman, S. Models for Natural Resource Management and Planning. Appl. Sp. Anal. Policy 2010, 3, 71-73.

43. Pollution Control Department. Air and Noise Quality Standards. Available online: http://www.pcd.go.th/info_serv/en_reg_std_airsnd.html (accessed on 27 June 2012).

44. Viwatpanich, K. Suffering from Industrial Estate Development: A Case Study in Map Ta Phut, Thailand. Available online: http://jr.sherubtse.edu.bt/index.php/pd1/article/view/35 (accessed on 1 August 2013).

45. Aruninta, A. Green Design and Planning Resolutions for an Eco-Industrial Town: A Case Study of Polluted Industrial Estate in Rayong Province, Thailand. J. Environ. Prot. 2013, 3, 1551-1558.

46. Pollution Control Department. Water Quality Standards. Available online: http://www.pcd.go.th/ info_serv/en_reg_std_water.html (accessed on 27 July 2013).

47. Industrial Estate Authority of Thailand. Environment and Safety al Management: Map Ta Phut Pollution. Available online: http://www.mtpie.com/envmnmt/mn_envmnmt.htm (accessed on 16 April 2014).

48. Vichit-Vadakan, N. Health Impact from Industry Study; Thammasat University: Bangkok, Thailand, 2010.

49. Kondo, M.; Limjirakan, S. Perceptions of Private Sector towards the Pollutant Release and Transfer Register: A Case Study on Petrochemical Industry in Map ta Phut Industrial Estate, Rayong, Thailand. Available online: http://www.oalib.com/paper/2841625 (accessed on 29 January 2014).

50. Wang, W.; Thampanishvong, K.; Chavanasporn, W. Investment in Pollution Abatement Technology in Response to Community Protests: Lessons from Map Ta Phut Industrial Estate. TDRI Q. Rev. 2011, 6, 15-23. 
51. Trong-ngam, S. Map Ta Phut Episode 5: Issues of Justice and Law: What is a Law without Enforcement? Available online: http://www.tuhpp.net/files/E5.pdf (accessed on 29 January 2014).

52. Tuler, S.; Langkulsen, U.; Chess, C.; Vichit-Vadakan, N. Health and Environmental Risk Communication in Thailand: An Analysis of Agency Staff's Perspectives on Risk Communication with External Stakeholders. Available online: http://www.seas.at/aseas/5_1/ASEAS_5_1_A4.pdf (accessed on 30 January 2014).

(C) 2014 by the authors; licensee MDPI, Basel, Switzerland. This article is an open access article distributed under the terms and conditions of the Creative Commons Attribution license (http://creativecommons.org/licenses/by/3.0/). 